\title{
UNFAIR LABOR PRACTICES UNDER THE WAGNER ACT'
}

\author{
ROBRRt H. Wettach*
}

The tide of injunction suits against the National Labor Relations Board and its officers has now definitely receded. During the first two years of its existence, 95 such suits were filed in federal district courts. ${ }^{2}$ Although 73 of these injunctions were denied when first presented, those issued seriously hampered the work of the Board and raised doubts as to its authority. The doubts were resolved in the Board's favor on January 3r, 1938, when the Supreme Court ${ }^{3}$ upheld the "exclusive initial jurisdiction" of the Board as conferred upon it by Congress in Section ro of the Wagner Act. ${ }^{4}$ This grant of exclusive power was held to be constitutional for the following reasons: ( $r$ ) the Act provides for appropriate procedure before the Board, including proper notice and hearing, ${ }^{5}(2)$ the provisions for review by Circuit Courts of Appeals ${ }^{\mathbf{b}}$ afford adequate opportunity to secure judicial protection against possible illegal action on the part of the Board, (3) the Board has no power to enforce obedience to its own orders, but must apply to the Circuit Courts of Appeals for affirmance of its orders before any penalties accrue for disobedience, ${ }^{\top}$ (4) that equity will not act to relieve from a threatened injury until the prescribed administrative remedy has been exhausted. Thus hearings of the Board will no longer be blocked by

*A.B., 1913, M.A., 1914, LL.B., 19r7, University of Pittsburgh; S.J.D., I921, Harvard University. Professor of Law, University of North Carolina. Special Examiner for Textile Labor Relations Board, 1934-1935, in cases arising under NIRA $\$ 7$ (a). Contributor to legal periodicals.

${ }^{1}$ A recent discussion of the subject matter of the present article appears in The Labor Board and the Courts. Unfair Labor Practices of the Employer (1938) 32 ILx. L. Rev. 568. Excellent summaries of the Board's decisions occur in the first and second annual reports of the National Labor Relations Board.' See also, The National Labor Relations Board-Decisions of its First Year (I936) 4 U. of CHI. L. Rev. 97. For a discussion of the decisions of the old National Labor Relations Board, see The Decisions, of the National Labor Relations Board (1935) $48 \mathrm{HARv}$. L. Rev. 630. The material in the present discussion necessarily duplicates much that will be found in the annual reports of the Board and in the recent Illinois Law Review article. No attempt will here be made to appraise the Wagner Act or the work of the Board.

${ }^{2}$ NLRB, Second ANwual Report (1937) 31-40.

${ }^{3}$ Myers v. Bethlehem Shipbuilding Corp., 58 Sup. Ct. 459 (1938); Newport News Shipbuilding etc. Co. v. Schauffler, 58 Sup. C. 466 (1938).

49 STAт. 449 (1935); 29 U. S. C. A. $\$ \$ 151-166$ (Supp. 1937). The original section numbers of the Wagner Act will be used throughout.

Section 1o(a) provides, "The Board is empowered, as hereinafter provided, to prevent any person from engaging in any unfair labor practice (listed in Section 8) affecting commerce. This power shall be cxclusive, and shall not be affected by any other means of adjustment or prevention that has been or may be established by agreement, code, law, or otherwise."

\footnotetext{
${ }^{3} \S \mathbf{I O}(\mathrm{b})$.

¡10(f).

- $10(\mathrm{e})$.
} 
the courts, and, subject only to the judicial control set out in the Act, the Board is free to investigate charges of unfair labor practices under the Act without judicial interference.

Section 7 of the Wagner Act guarantees to employees the right to self-organization, to form, join or assist labor organizations, to bargain collectively through representatives of their own choosing and to engage in concerted activities for the purpose of collective bargaining or other mutual aid or protection. Section 8 implements these rights by providing, in successive sub-sections, that it shall be an unfair labor practice for an employer:

(1) To interfere with, restrain, or coerce employees in the exercise of the rights guaranteed in Section 7 .

(2) To dominate or interfere with the formation or administration of any labor organization or contribute financial or other support to it.

(3) By discrimination in regard to hire or tenure of employment or any term or condition of employment to encourage or discourage membership in any labor organization.

(4) To discharge or otherwise discriminate against an employee because he has filed charges or given testimony under this Act.

(5) To refuse to bargain collectively with the representatives of his employees, subject to the provisions of Section 9(a), prescribing means for the determination of employee representatives.

"8 (5)" is the subject of discussion in a separate article, ${ }^{8}$ so the present discussion will include only those unfair labor practices proscribed in the first four subdivisions of Section 8.

A detailed account of the unfair labor practices in the Pennsyluania Greyhound case $^{9}$ may be used for purposes of illustration. Prior to the Fall of 1933 , the employees were unorganized. In July, 1933, the management decided that the employees ought to be organized. The impact of the NRA and conferences of employer groups convinced big business that organization of employees was all right-if the employer could control it. The employees of the Pennsylvania Greyhound Lines had made no demand for any form of organization. In a letter from the General Manager of Maintenance to various subordinate executives of the Company, including the Superintendent of the Pittsburgh Garage, it was stated, "The management has decided to set up a plan of employee representatives. . . . It is to our interest to pick out employees to serve on the Committee who will work for the interest of the company and will not be radical."10

Petitions were drawn up requesting an election by employees for the purpose of selecting representatives. Employees selected by the management to circulate these petitions stated that "Crawford (Regional Manager) instructed us since the NRA came along that we have to have an organization." ${ }^{11}$ Employees were then elected

\footnotetext{
${ }^{8}$ Wolf, The Duty to Bargain Collectively, infra, p. ooo.

- Pennsylvania Greyhound Lincs, Inc., I N.L.R.B. I (1935).

${ }^{20} 7 d$. at 8.

11 lbid.
} 
as regional committeemen, who in turn chose a regional chairman. These regional chairmen met with representatives of the management. At the first meeting, which was for organization purposes, the management presented mimeographed by-laws and regulations for the approval of the employee representatives. These were modified in minor details, but the by-laws and regulations were never presented to the entire group of employees for approval. The company provided all mimeographed petitions, all ballots, the lists of employees eligible to vote, and, in addition, the petitions were circulated by employees on company time and the elections were held on company time and company property. Although instructions to regional managers were to the effect that the election was to be conducted by the employees, yet the management controlled it at every step.

Membership in the Employees Association was automatic after three months employment. No outside person or organization might represent the employees, as employees alone were eligible for the office of representative. The by-laws could be amended only by two-thirds vote of a joint reviewing committee, membership on which was equally divided between the employees and the management, the chairman, however, being a company executive, the regional manager. Consequently, the management had a veto power over any proposed changes in the by-laws of the Employees Association. There were no provisions for meetings of employees and so no method of giving instructions to employee representatives.

All employee representatives doing committee work were paid for time off at regular rates of pay, and free transportation was also provided in addition to expenses where travel was involved. The employees paid no dues and all expenses in connection with the Employees Association were borne by the management. No matter could be discussed by the joint reviewing committee if a department head refused to submit it for discussion. Thus the employee representation plan did not provide, and was obviously not intended to provide, an avenue for collective bargaining. It was solely for the purpose of handling individual employee grievances.

This is a typical picture of an employee representation plan, the creature of the management at every stage and providing for no real collective bargaining with representatives chosen freely by the employees. The management's domination, interference and support were clearly unfair labor practices proscribed by "8 (2)."

In May, 1935, a charter for a local union of the Amalgamated Association of Street, Electric Railway and Motor Coach Employees of America was secured by a number of Pennsylvania Greyhound employees who had become dissatisfied after two years of the Employees Association. Management opposition to an outside union at once showed itself. On repeated occasions, the Superintendent of the Pittsburgh Garage of the Greyhound Lines questioned employees about the union and warned and advised individual employees not to join, telling one man to keep out of the union if he and his kids and wife did not want to go hungry, and telling another that he had investigated unions and found they were no good. Attempts were made to obtain the names of employees who were union members, and company officials 
sat in a car parked near the entrance of the meeting place and observed employees who were entering. An employee, hired to get information about union activities, tried to find out who attended the union meetings by copying the license numbers of the cars parked outside. When another employee was demoted, the garage foreman said, "You should have kept your nose clean and stayed out of the union."12 Testimony of this sort was not sufficiently counteracted by later testimony of company officials asserting complete indifference and ignorance about the type of meeting their employees were holding. This open surveillance of union meetings, coupled with threats of discharge, is clearly a violation of " 8 ( $\mathrm{r}$ )."

As to actual discharges which took place, the complaint alleges discharge for union membership or activity. The management advanced other reasons for the discharges, such as, the transfer of some of the work from the Pittsburgh Garage to other places; a desire to correct the supposedly inefficient work being performed at the garage alleged to have resulted in excessive road failures; a change in classification which showed that the discharged men were junior men in their respective classifications; and individual charges of inefficiency or failure to observe rules: The Board had to weigh the reasons advanced for the discharge in each case against the background of open hostility to the union. The men who were discharged were among the older and more dependable employees and had good service records. They were not responsible for the road failures and employees more nearly responsible were not discharged. Moreover, the change in classification of employees had actually resulted in depriving the discharged employees of their full seniority. The Board concluded that five of the employees were discharged because of union membership and activity, thus constituting a violation of " 8 (3)." It was pointed out that the discharges came at a time when the union was rapidly gaining strength and the discharged men were known to be union members and had all been threatened or warned about the union by company officials. So the Board's inference that these employees were chosen as examples for discharge primarily because of their union membership is supported by sufficient evidence.

The case finally reached the Supreme Court which decided on February 28, 1938, that the entire order of the Board should be enforced, ${ }^{13}$ contrary to the Circuit Court of Appeals of the Third Circuit which refused to enforce part of it. Both courts agreed that the order was valid to the extent of requiring the company to offer to the five discharged men immediate and full reinstatement to their former positions and to reimburse them for any losses of pay suffered, less what they earned subsequent to discharge. The Third Circuit Court of Appeals refused to enforce that part of the Board's order requiring the Company to withdraw all recognition from the Em-

"Id. at 19.

${ }^{13}$ NLRB v. Pennsylvania Greyhound Lines, Inc., 58 Sup. Ct. 571 (1938). rev'g NLRB v. Pennsylvania Greyhound Lines, Inc., 9I F. (2d) 778 (3rd, 1937). Cf. NLRB v. Remington-Rand, Inc., 94 F. (2d) 862 (2nd, 1938). (The Board had ordered the respondent to withdraw all recognition from the Remington. Rand Employees Associations as representatives of its employees and "completely disestablish those associations as such representatives." The court struck out the quoted words from the Board's order.) 
ployees Association and to post notices stating that said association is disestablished and that the company will refrain from any recognition thereof. This was held to be an outlawing of the company union in advance of an election and without a hearing. But the Supreme Court, relying on the Railway Labor Act cases, held that employer recognition of a company union might be enjoined and the union "disestablished," as an appropriate means of preventing interference with the rights secured to employees by the statute. This order is thus adapted to the needs of the particular case and secures to employees the right to bargain with representatives of their own choosing free from employer restraints. The Pennsylvania Greyhound case was decided at the same time as the Pacific Greyhound case, ${ }^{14}$ in which the Supreme Court affirmed the decision of the Ninth Circuit Court of Appeals which had in turn decreed the enforcement of an order of the Board containing similar provisions as to reinstatement of discharged employees and disestablishment of the company union.

\section{INterference with Workers' Rights of Self-Organization '}

"8 (I)" condemns as an unfair labor practice interference with, restraint or coercion of employees in the exercise of the rights guaranteed in Section 7 , namely, the rights of self-organization, to form, join, or assist labor organizations, to bargain collectively through representatives of their own choosing, and to engage in concerted activities for the purpose of collective bargaining or other mutual aid and protection. This subdivision has been termed, "a catch-all, designed to include not only the more prevalent and troublesome practices spelled out with particularity in the four succeeding subdivisions, but all other tactics, impracticable to define or unanticipated, used by employers to bar effective organization and genuine bargaining." 15 The Board has held that a violation by an employer of any other of the four subdivisions of Section 8 is also a violation of " 8 ( 1 )."16 The explanation given for this is that even though an employer may be engaging in anti-union activities in violation of "8 ( 1 )," unions do not seek the protection of the Act until such activities take such drastic form as to bring them within the provisions of some other subdivision. Therefore in most of the cases involving " 8 (I)," the principal offense charged fell within some other subdivision of Section 8, and as in the Pennsylvania Greyhound case, we find combinations of unfair labor practices. Nevertheless, there are elements in the cases involving " $8(\mathrm{r})$ " which are not appropriate to the other sections, i.e., unfair employer tactics not defined except in the general terms of Section 7 .

A most extensive array of violations of " $8(\mathrm{I})$ " is present in the Remington-Rand case. ${ }^{17}$ There a joint protective committee, representing a clear majority of production and maintenance employees at the various plants involved, and affiliated with

\footnotetext{
"NLRB v. Pacific Greyhound Lines, Inc., 58 Sup. Ct. 577 (1938), aff'g NLRB v. Pacific Greyhound Lines, Inc., 91 F. (2d) 458 (9th, I937).

${ }^{15}$ (I938) 32 Ill. L. Rev. 568, 589. ${ }^{16}$ NLRB, First Awnual Report (1936) 7 .

${ }^{17}$ Remington-Rand, Inc., 2 N.L.R.B. 626 (1937). The Board's order was enforced with some modifications in NLRB v. Remington-Rand, Inc., supra note $\mathrm{r}_{3}$.
} 
the A. F. of L., had been met by a refusal, on the part of the management, to negotiate in good faith. This precipitated a strike. The company not only continued its refusal to bargain with the joint protective committee but set out to destroy the free organization of its employees. There, was a wholesale utilization of professional labor spies, "undercover" men, "missionaries," guards, provocateurs and strikebreakers, supplied by four leading strike-breaking agencies, those headed respectively by Pearl L. Bergoff, Capt. Robert L. Foster, R. J. Burns and Capt. Nat Shaw. Bergoff alone supplied 200 men and women "missionaries." The Remington-Rand plan for breaking the strike was described in narrative form in the Labor Relations Bulletin of the National Association of Manufacturers and was christened by Rand, "the Mohawk Valley Formula." The National Labor Relations Board repeats in the Remington-Rand opinion this technique of strike breaking, interpolating its own interpretations, as follows:

"First: When a strike is threatened, label the union leaders as 'agitators' to discredit them with the public and their own followers. In the plant, conduct a forced balloting under the direction of foremen in an attempt to ascertain the strength of the union and to make possible misrepresentation of the strikers as a small minority imposing their will upon the majority. At the same time, disseminate propaganda, by means of press releases, advertisements, and the activities of 'missionaries', such propaganda falsely stating the issues involved in the strike so that the strikers appear to be making arbitrary demands, and the real issues, such as the employer's refusal to bargain collectively, are obscured. Concurrently with these moves, by exerting economic pressure through threats to move the plant, align the influential members of the community into a cohesive group opposed to the strike. Include in this group, usually designated a 'Citizens Committee,' representatives of the bankers, real estate owners, and businessmen, i.e., those most sensitive to any threat of removal of the plant because of its effect upon property values and purchasing power flowing from pay rolls.

"Second: When the strike is called raise high the banner of 'law and order', thereby causing the community to mass legal and police weapons against a wholly imagined violence and to forget that those of its members who are employees have equal rights with the other members of the community.

"Third: Call a 'mass meeting' of the citizens to coordinate public sentiment against the strike and to strengthen the power of the Citizens Committee, which organization, thus supported, will both aid the employer in exerting pressure upon the local authorities and itself sponsor vigilante activities.

"Fourth: Bring about the formation of a large armed police force to intimidate the strikers and to exert a psychological effect upon the citizens. This force is built up lyy utilizing local police, state police, if the Governor cooperates, vigilantes, and special deputies, the deputies being chosen if possible from other neighborhoods, so that there will be no personal relationships to induce sympathy for the strikers. Coach the deputies and vigilantes on the law of unlawful assembly, inciting to riot, disorderly conduct, etc., so that, unhampered by any thought that the strikers may also possess some rights, they will be ready and anxious to use their newly acquired authority to the limit.

"Fifth: And perhaps most important, heighten the demoralizing effect of the above measures-all designed to convince the strikers that their cause is hopeless-by a 'back-towork' movement, operated by a puppet association of so-called 'loyal employees' secretly organized by the employer. Have this association wage a publicity campaign in its own 
name and coordinate such campaign with the work of the 'missionaries' circulating among the strikers and visiting their homes. This 'back-to-work' movement has these results: It causes the public to believe that the strikers are in the minority and that most of the employees desire to return to work, thereby winning sympathy for the employer and an endorsement of his activities to such an extent that the public is willing to pay the huge costs, direct and indirect, resulting from the heavy forces of police. This 'back-to-work' movement also enables the employer, when the plant is later opened, to operate it with strikebreakers if necessary and to continue to refuse to bargain collectively with the strikers. In addition, the 'back-to-work' movement permits the "employer to keep a constant check on the strength of the union through the number of applications received from employees ready to break ranks and return to work, such number being kept secret from the public and the other employees, so that the doubts and fears created by such secrecy will in turn induce still others to make applications.

"Sixth: When a sufficient number of applications are on hand, fix a date for an opening of the plant through the device of having such opening requested by the 'back-to-work' association. Together with the Citizens Committee, prepare for such opening by making provision for a peak army of police by roping off the areas surrounding the plant, by securing arms and ammunition, etc. The purpose of the 'opening' of the plant is threefold: To see if enough employees are ready to return to work; to induce still others to return as a result of the demoralizing effect produced by the opening of the plant and the return of some of their number; and lastly, even if the maneuver fails to induce a sufficient number of persons to return, to persuade the public through pictures and news releases that the opening was nevertheless successful.

"Seventh: Stage the 'opening,' theatrically throwing open the gates at the propitious moment and having the employees march into the plant grounds in a massed group protected by squads of armed police, so as to give to the opening a dramatic and exaggerated quality and thus heighten its demoralizing effect. Along with the 'opening' provide a spectacle-speeches, flag raising, and praises for the employees, citizens, and local authorities, so that, their vanity touched, they will feel responsible for the continued success of the scheme and will increase their efforts to induce additional employees to return to work.

"Eighth: Capitalize on the demoralization of the strikers by continuing the show of police force and the pressure of the Citizens Committee, both to insure that those employees who have returned will continue at work and to force the remaining strikers to capitulate. If necessary, turn the locality into a warlike camp through the declaration of a state of emergency tantamount to martial law and barricade it from the outside world so that nothing may interfere with the successful conclusion of the 'formula,' thereby driving home to the union leaders the futility of further efforts to hold their ranks intact.

"Ninth: Close the publicity barrage, which day by day during the entire period has increased the demoralization worked by all of these measures, on the theme that the plant is in full operation and that the strikers were merely a minority attempting to interfere with the 'right to work,' thus inducing the public to place a moral stamp of approval upon the above measures. With this, the campaign is over-the employer has broken the strike."18

All the activities in the Remington-Rand case employed to end the strike by breaking it, rather than by settling it through collective bargaining, were held to constitute a violation of " $8(\mathrm{I}) . .10$

${ }^{28} 2$ N.L.R.B. $626,664-666$.

${ }^{10}$ Cf. Ford Motor Co., 4 N.L.R.B. No. 81 (1937). (Union organizers attempting to distribute literature at plant beaten by groups which included foremen, service department and other employees. The service 
Espionage and union surveillance constitute unfair labor practices under "8 $(\mathrm{I})$, even where no discriminatory discharge results, if the effect is to intimidate employees from joining a labor organization of their own choosing. In the Fruehauf Trailer case, ${ }^{20}$ the Supreme Court affirmed an order of the Board, ${ }^{21}$ directing the employer to cease and desist from employing detectives or any other person for purposes of espionage. In that case, the company hired a detective "to ferret out the union activities of the men"22 and to keep the company informed. The detective was given employment in order to make him eligible for membership in the union, and he joined and became its treasurer. Thus he secured a list of all union members, which he turned over to the management. In the Friedman-Harry Marks case, ${ }^{23}$ the Supreme Court affirmed the finding of the Board ${ }^{24}$ as to a violation of "8 ( $\mathrm{x}$ )," where the president and superintendent of the company secretly observed a union meeting and the president told an employee to attend union meetings and report names of those attending, paying her $\$ 22.50$ per week for her services. In the Washington, Virginia and Maryland Coach case, ${ }^{25}$ the vice-president of the company attended a union meeting wearing a bus driver's cap. In the more recent cases, the Board continues to treat espionage and surveillance of union meetings, whether done by outsiders or insiders, by employees or management, as violative of "8 (r)."26

Another group of cases held to violate "8 (I)" involves in general the spread of anti-union propaganda which tends directly or indirectly to coerce workers in the matter of self-organization. The most direct form of this is where supervisory officials warn employees against engaging in union activity. ${ }^{27}$ But it may consist in statements which tend to discredit the union, as warning against the labor racketeers, ${ }^{28}$ or that any outside union would destroy employer-employee harmony, ${ }^{20}$ or warnings by supervisory officials against union activity and prohibiting all propaganda during working hours while at the same time posting a notice that the management favored an employee-organization, ${ }^{30}$ or discriminatory remarks against the union and putting an anti-C. I. O. advertisement in the local newspaper. ${ }^{31}$

department had been greatly increased in size by the addition of some professional fighters and individuals with known criminal records); Jones and Laughlin Steel Corp., I N.L.R.B. 503 (1936).

${ }^{20}$ Fruehauf Trailer Co., r N.L.R.B. 68 (1935).

${ }^{2}$ NLRB v. Fruehauf Trailer Co., 301 U. S. 49 (1937).

* Friedman-Harry Marks Clothing Co., Inc., I N.L.R.B. 411 (1936).

(1935) I N.L.R.B. 68, 73.

${ }^{2}$ NLRB v. Friedman-Harry Marks Clothing Co., Inc., 301 U. S. 58 (1937).

${ }^{25}$ Washington, Virginia and Maryland Coach Co., I N.L.R.B. 769 (1936).

${ }^{20}$ National Electric Products Corp., 3 N.L.R.B. No. 47 (1937) (surveillance over meetings and meeting places); Stylecraft Leather Goods Co., Inc., id. No. 98 (1937) (watching employec active in union); Consolidated Edison Co. of N. Y. Inc., 4 id. No. ro (1937) (previous employment of industrial spies); Botany Worsted Mills, id. No. 43 (1937) (where anti-union employee watched fellow worker turn in executed union application and reported it, held encouragement of systematic espionage); Metropolitan Engineering Co., id. No. 73 (1937); Jacob Cohen, id. No. 87 (1937); Cating Rope Works, Inc., id. No. 124 (1938).

${ }^{7}$ Metropolitan Engineering Co., 4 N.L.R.B. No. 73 (1937); Washington Manufacturing Co., id. No. 120 (1938); Trenton Garment Co., id. No. 142 (1938); Montgomery Ward and Co., id. No. 138 (1938). In Greensboro Lumber Co., I id. 629 (1936), employees were called in one by one and asked bluntly concerning union activity.

${ }^{x}$ Ralph A. Freundlich, Inc., 2 N.L.R.B. 802 (1937); Leo L. Lowy, 3 id. No. Ior (1937).

S. Blechman \& Sons., Inc., 4 N.L.R.B. No. 3 (1937).

${ }^{30}$ Federal Bearings Co., Inc., 4 N.L.R.B. No. 66 (1937).

${ }^{s 1}$ Bradford Dyeing Ass'n, 4 N.L.R.B. No. 79 (1937). 
Much propaganda takes the form of economic coercion and is aimed at the worker's fear of the loss of his job, if the union succeeds. Threats to close $\mathrm{s}^{\mathbf{2}}$ or move the plant ${ }^{33}$ or to go out of business ${ }^{34}$ are effective in such mobile industries as clothing and shoes. In the Remington-Rand case, ${ }^{35}$ a "for sale" sign was placed on a factory building. The reaction of this in a community which depends for its economic life on the industry in question is hard to measure, but the pressure on the worker becomes well-nigh irresistible. The whole community lines up against the worker who holds out. In the Mansfield Mills case, ${ }^{36}$ a meeting was held on mill property and the Mayor of the mill town, who was an employee of the company, urged all who were loyal to the community to drive out the union organizer. A crowd then followed the Mayor to the organizer's house where the Mayor warned him that his union activity would cause violence. In one case, the company made threats to its employees and to the Chamber of Commerce that it would move its plant if the right bargaining representative was not seleced, ${ }^{\mathbf{3 7}}$ and in another, local business men, including municipal officers, leased the plant to respondents, and they threatened and assaulted union organizers. ${ }^{38}$

Economic coercion may take the form of threatened eviction from company houses, ${ }^{39}$ particularly where a mill village is entirely company owned. The policy in many cotton mill towns of discharging all members of a family in order to secure possession of a company house would seem to violate "8 (I)," especially if the first member of the family is wrongfully discharged under "8 (3)."40 In the Alaska Juneau case, ${ }^{41}$ the employer caused the food stores in the town to stop extending credit to employees engaged in union activities.

A failure of a shipping company to issue a pass to the bargaining representative of the employees, when passes had been issued to other labor organizations, was held to be an unfair labor practice. ${ }^{42}$ A similar result was reached where an employer sought to restrain union activities of an employee, who was secretary of the union commitee and a night law student, by threatening to inform the character committee of the Bar Association that he was a communist and engaged in union activities. ${ }^{43}$

${ }^{23}$ Leo L. Lowy, 3 N.L.R.B. No. 101 (1937); Idaho-Maryland Mines Corp., 4 id. No. 97 (1938) (mine shaft where unionization most active was shut down).

${ }^{20}$ Friedman-Harry Marks Clothing Co., Inc., 1 N.L.R.B. 4 II (1936); Anwelt Shoe Mfg. Co., id. 939 (1936); Omaha Hat Corp., 4 id. No. 106 (1938).

"National Casket Co., Inc., I N.L.R.B. 963 (1936); Remington-Rand, Inc., 2 id. 626 (1937).

supra note 34 .

${ }^{7}$ Lenox Shoe Co., 4 N.L.R.B. No. 54 (1937).

${ }^{36}$ Mansfield Mills, Inc., 3 N.L.R.B. No. 97 (1937).

${ }^{8}$ Regal Shirt Co., 4 N.L.R.B. No. 74 (1937).

- Carlisle Lumber Co., 2 N.L.R.B. 248 (1936). References to eviction from company houses or notices of eviction are found in Alabama Mills, Inc., id 20 (1936); Hardwick Stove Co., Inc., id. 78 (1936).

"Cf. Quidnick Dye Works, Inc., 2 N.L.R.B. 963 (I937) (violation of "8 (3)" to discharge employee because he is brother of union worker previously discharged).

"Alaska Juneau Gold Min. Co., 2 N.L.R.B. 125 (1936).

${ }^{2}$ Seas Shipping Co., Inc., 4 N.L.R.B. No. 88 (1938); cf. American France Lines, 3 id. No. 7 (1937) (companies forbidden to show preference to any labor organization by way of free passes, as that would constitute an interference with the election).

"Elbe File and Binder Co., Inc., 2 N.L.R.B. 906 (1937). Distribution of photostatic copies of a C.I.O. organizer's affidavit of registration for the Communist Party primaries was held an unfair labor practice, although the information was true. National Motor Bearing Co., 5 id. No. 66 (1938). 
A new corporation which took over part of the work of the respondent corporation was made a party by amending the complaint, because the Board found that the new corporation was formed to avoid the respondent's responsibility, and this was held to be an interference with the employees' self-organization in view of the respondent's anti-union attitude. ${ }^{44}$ A curious unfair labor practice is found in the Louisville Refining case, ${ }^{45}$ where, during attempted negotiations by the union, the management changed working hours and was held to have interfered with employees' selforganization.

Truly, "8 (I)" is a "catch-all," which the employer will have difficulty in avoiding and which will continue to enable the Board to checkmate new anti-union devices of employers.

\section{Company-dominated Unrons}

"8 (2)" makes it an unfair labor practice for an employer: "To dominate or interfere with the formation or administration of any labor organization or contribute financial or other support.to it." Committee reports in Congress on the Wagner Act showed that practically seventy percent of the company unions in existence in 1935 were established" after the passage of Section 7 (a) of NIRA and were a large factor in industrial disputes during that period.

The term "labor organization" is defined in Section 2(5) of the Wagner Act as "any organization of any kind, or any agency or employee representation committee or plan, in which employees participate and which exists for the purpose, in whole or in part, of dealing with employers concerning grievances, labor disputes, wages, rates of pay, hours of employment or conditions of work." The Act does not prevent an organization of employees limited to one company nor interfere with the freedom of employees to establish pension benefits, outing clubs, etc., as long as such organizations do not engage in collective bargaining and are not used for purposes of discriminating against or in favor of membership in any labor organization. On the other hand, no matter what form the organization takes, good-will club, employee representation plan, back-to-work association, if it exists in part for the purpose of dealing with employers concerning those matters specified in Section 2 (5), it is a labor organization within the terms of the Act. Employer control does not prevent the description of "labor organization" and calling it a "labor organization" does not confer any particular legitimacy upon it. It is a term used "in a special and technical sense solely for the purpose of statutory draftsmanship and to make the prohibition of Section 8, subdivision (2) all inclusive. That prohibition was intended to apply to any device which would tend to displace, or masquerade as, a genuine labor organization, whether it was itself such a genuine organization or not."46

\footnotetext{
"Hopwood Retinning Co., Inc. and Monarch Retinning Co., Inc., 4 N.L.R.B. No. 113 (1938). In Cardinale Trucking Corp., 5 id. No. 33 (1938), the discharged employees were from a shop which was leased to a company financed by, and completely subject to, the respondent.

Louisville Refining Co., 4 N.L.R.B. No. I 10 (1938).

"International Harvester Co., 2 N.L.R.B. 310, 353 (1936).
} 
Company union plans held in violation of "8 (2)" vary in details but the description of the Employees Association in the Pennsylvania Greyhound case may be taken as fairly typical. In the Pacific Greyhound case, ${ }^{47}$ a Drivers' Association was likewise effectively controlled by the employer, and the Board had the following to say,

"The presence of the respondent's officers at the meetings of the Drivers' Association, 'taking notes of the proceedings' and joining in the discussion of working conditions and proposals for changes in the so-called working agreement, exerts a powerful pressure upon the members and representatives to do as the respondent bids. The respondent's zealous interest in the affairs and the expansion of the Drivers' Association has made it apparent to the operators that this is the organization which the respondent favors and which it would be wise to join. By gratuitously supplying the Drivers' Association with secretarial help, stationery, and meeting places, by supporting its members and their representatives while engaged in its affairs by payment to them of their regular wages, and by collecting the dues of the Drivers' Association, the respondent has clearly identified itself with that organization in the eyes of its operators and has impaired the bargaining power of the Drivers' Association by placing it in the position of a debtor." 48

Employer control is not limited to company unions, but may extend to locals of the A. F. of L. or the C. I. O. ${ }^{48}$ This has given rise to A. F. of L.-C. I. O. rivalry ${ }^{50}$ and has involved the Board in a controversy with the federal courts in the Ambridge case. $^{51}$ The Board found in that case that C. I. O. had commenced organization work almost a year before the A. F. of L. and had gr8 members of the appromixately $16 \mathrm{Iz}$ employees on a certain date, about the time the A. F. of $\mathrm{L}$. began to organize. The Board concluded that the respondent (National Electric Products Corporation) urged, persuaded and warned its employees to refrain from joining or remaining members of the United (C.I.O.) and to become members of the Brotherhood (A.F. of L.) and threatened them with discharge if they did not comply. Employees and foremen solicited membership applications for the Brotherhood on company time, the power sometimes being shut down while solicitation was going on. The respondent agreed to recognize the Brotherhood as the exclusive representative of its employees at a time when it had not, to the respondent's knowledge, been designated as the free choice of a majority of its employees and when the United had asserted that it represented a majority. The respondent refused to negotiate with or interview the officers of the United, and instead speedily granted the Brotherhood's request for a conference and entered into a closed shop agreement, which required all employees to join the

${ }^{47}$ Pacific Greyhound Lines, Inc., 2 N.L.R.B. 43 (1936).

${ }^{49}$ Id. at 455 .

${ }^{6}$ National Electric Products Corp., 3 N.L.R.B. No. 47 (1937); Consolidated Edison Co. of N. Y., 4 id. No. 10 (1937); Lenox Shoe Co., id. No. 54 (1937); Pacific Greyhound Lines, id. No. 72 (1937).

${ }^{\text {to }}$ The National Labor Relations Board Faces A. F. of L.-C. I. O. Rivalry (r937) 6 I. J. A. MonthLY Btill. 4r.

"1 National Electric Products Corp., 3 N.L.R.B. No. 47 (1937). Aceord: Consolidated Edison Co. of N. Y., Inc., 4 id. No. ro (1937) (after the National Labor Relations Act was held constitutional, the management thought that the Employees' Representation Plans would be in violation of the Act and arranged to deliver the Plan organizations to the Brotherhood (A. F. of L.) and hurriedly made contracts with the Brotherhood, at a time when it was doubtful if the Brotherhood represented a majority of the workers.) Order entered for enforcement of Board's order by Second Circuit Court of Appeals on March 14, 1938. Consolidated Edison Co. of N. Y., Inc. v. NLRB, C. C. H. LABOR L. SERv. par. I8224. 
Brotherhood or have deducted from their wages sums of money equivalent to Brotherhood dues. The United then called a strike which closed the plant for three weeks and which was called off on condition that all employees would be returned to work without discrimination. The Brotherhood then sued the respondent for specific performance of its agreement, and the United States District Court for the Western District of Pennsylvania entered a decree of specific performance, thus upholding the agreement. The Board, without taking sides in the union rivalry, held that even a bona fide union could be the instrument for employer control and unfair labor practices, that the district court action was a suit between private parties in which the issue of unfair labor practices under the Wagner Act was not raised or decided, and that the National Labor Relations Board had exclusive jurisdiction under the Act to decide those issues. Therefore the Board held the agreement void and ordered the respondent to cease and desist its unfair practices. The Board thus upheld the right of self-organization which both labor groups are fighting for.

More subtle and indirect are other employer efforts to dominate or interfere with employee-organization. Fostering a back-to-work movement and using public offcials and citizens' committees to help secure control of labor organizations is much more insidious, as the real issues become completely clouded and community hysteria is enlisted against free organization. The Remington-Rand case shows this clearly, as already set out in the Mohawk Valley formula. In the Alaska Juneau Gold Mining Company case, ${ }^{52}$ a strike had been called by an independent union. A back-to-work movement was commenced by a group of employees, encouraged by the mine superintendent. The city council intervened in response to petitions, and the city attorney, who was directly interested in the Mining Company and had acted as its attorney and lobbyist, assumed an important role. The Board's comments on his conduct follow:

"In evaluating the connection between the respondent and the Association (company union) the omnipresent figure of Mr. Faulkner (city attorney) must be taken into account. It was he who assisted the movement to return to work in its incipiency; it was he who brought to bear the full weight of the authorities on the side of those seeking to break the strike; it was he who drew up the resolution calling for a vote on the question of returning to work; it was he who drafted the Police Protection Resolution; it was he who addressed the workers at the Association meeting and urged them to go back to work; it was he who warned the pickets to disperse; it was he who paid the fare and expenses of Danielson, first president of the Association, to Seattle; it was he who wrote the anonymous letter condemning the jury for acquitting the strikers charged with rioting; and in all this by his own admission he did not act in his capacity as city attorney. And, admittedly, he was in frequent conferences with Metzgar (mine superintendent) after the strike was called. Indeed, so universally did the idea gain acceptance that Faulkner was acting in behalf of the respondent. ..."53

The Board held that by this indirect and clandestine course of conduct, the respondent dominated and interfered with the formation of the Association.

${ }^{82}$ Alaska Juneau Gold Mining Co., 2 N.L.R.B. 125 (1936).

${ }^{20} 2$ N.L.R.B. $125,135$. 
In the cases under this section, when a strike has not been called by an independent union, we are likely to find such a union in existence and engaged successfully in organizing the workers, and the employer is consequently engaged in counteracting such organization. The following are some of the obvious acts of interference found in most of the cases: (I) initial creation of the company union, (2) financial support, (3) by-laws dictated by the management, which puts the control of the union in the hands of the management, (4) intimidation of employees into membership, (5) leadership of the union by supervisory émployees, (6) no dues or assessments, (7) no problems discussed without consent of management, (8) no referendum by employees or meetings for purpose of instructing their representatives, and (9) entering into closed shop agreements after employer control is established.

When the Board finds these elements present in various combinations ${ }^{54}$ and holds that a particular labor organization is employer-controlled, the only effective order is the one upheld in the Pennsylvania Greyhound case ${ }^{55}$ by the Supreme Court, the order to "disestablish." Orders to cease and desist may not eliminate all domination. As a practical matter, when the Board's order to cease and desist has apparently been obeyed, the employee may feel that there is no further reason to withdraw from the company union. Theoretically, it is now free from employer control. He may decide to remain a member from sheer inertia, since the organization, now shorn of employer domination, is recognized as a proper labor organization for collective bargaining. Workers should really have a chance to express themselves as if the issue were presented for the first time and so be free to decide whether to continue in the company union or not. The order to disestablish gives the opportunity for a fresh start and is consistent with the policy of the Wagner Act to enable the worker to join the labor organization of his choice, free from direct or indirect control or interference by his employer.

\section{Discrimination Affecting Union Membership}

"8 (3)" makes it an unfair labor practice for an employer "By discrimination in regard to hire or tenure of employment or any term or condition of employment to encourage or discourage membership in any labor organization." As interpreted by the Board, "this section is not intended to interfere generally with the freedom of an employer to hire and discharge as he pleases. It limits this freedom, however, in one

"Canadian Fur Trappers Corp., 3 N.L.R.B. No. 63 (1937) (coercion to join Protective Association and closed shop agreement with it); Highway Trailer Co., id. No. 65 (r937) (during strike shop union formed with company aid in membership campaign and foremen as members); Ford Motor Co., $4 \mathrm{id}$. No. 81 (1937). (Ford Brotherhood of Am. solicited membership during working hours, encouraged by foremen); Metropolitan Engineering Co., 4 N.L.R.B. No. 73 (supervisory officials members of Employees Association); Regal Shirt Co., id. No. 74 (I937) (meetings of Association permitted in plant during working hours and agreement with it made in summary manner); David and Hyman Zoslow, id. No. 112 (1938) (order to withdraw all recognition from company union and to take legal means to secure surrender of company-union's charter); Associated Press, id. No. 140 (1938) (Independent Employees Guild, Inc. as bargaining agency fostered by Associated Press); Montgomery Ward and Co., Inc., id. No. 138 (1938) (supervisory employees aided in forming company-union and memberships solicited during working hours).

${ }^{u}$ Stupra note 13. 
important respect. He may not use it in such a manner as to foster or hinder the growth of a labor organization. He may employ anyone or no one, he may transfer employees from task to task within the plant as he sees fit; he may discharge them in the interest of efficiency or from personal animosity or sheer caprice. But, in making these decisions he must not differentiate between one of his employees and another, or between his actual and his potential employees, in such manner as to encourage or discourage membership in a labor organization." 56

There are cases where employees have been openly discharged for taking part in union activities. ${ }^{57}$ For instance, in discharging a waiter, the head waiter said, "If you want to know why you are fired, the reason is the union." 58 In the same case, the president of the company greeted several waiters with the following question and answer: "Are you with the union or not? If you are with the union you can not work here." ${ }^{59}$ The general manager of an express company in discharging an admittedly efficient truck driver told him that "he had orders from his main office to dispense with the service of all union men." ${ }^{\text {e0 }}$ Where a discharge follows shortly after election to a union office ${ }^{61}$ or after an employee has been seen attending a union 'meeting, ${ }^{62}$ the case of discrimination is only slightly less obvious. But in most cases, the employer has made no such frank admissions, and contends that the discharge has nothing to do with union activity but is the result of inefficiency, insubordination, infraction of rules, slowing of work, falling off of business, or other legitimate cause. Thus each case must be decided on its own facts.

In the previously discussed Pennsylvania Greyhound case, ${ }^{63}$ the five discharged employees were known to be union members and had been warned by company officials. At a time when the union was gaining strength, and in view of the antiunion attitude of the company, the reasons advanced for discharging the five men, such as transferring work to other garages, inefficiency, etc., were regarded as mere pretexts to cover up the real reasons, -i.e., union activity. In the Jones and Laughlin case, ${ }^{64}$ the discharges followed a pattern. All of the discharged employees were active in union work, several being officers. They were old employees with excellent service records. Then suddenly they were discharged for some routine fault or omission, to which, normally, no penalty or only slight penalty attached. One man, for eight

${ }^{34}$ NLRB, FIrst A.ivual Report (1936) 77. In NLRB v. Jones \& Laughlin Stcel Corp., 30r U. S. r, 45-46 (r937), Hughes, C. J., affirmed this interpretation, as follows: "The Act does not interfere with the normal exercise of the right of the employer to select its employces or to discharge them. The $\mathrm{cm}$ ployer may not, under cover of that right, intimidate or coerce its employees with respect to their self. organization and representation, and, on the other hand, the Board is not entitled to make its authority a pretext for interference with the right of discharge when that right is exercised for other reasons than such intimidation and coercion."

3i Pennsylvania Greyhound Lines, Ine., I N.L.R.B. I (1935); Protective Motor Service Co., id. 639 (1936); National Electric Products Corp., 3 id. No. 47 (1937).

3 Club Troika, Inc., 2 N.L.R.B. 90, 93 (1936).

so Ibid.

${ }^{00}$ Tidewater Express Lines, Inc., 2 N.L.R.B. 560, 563 (1937).

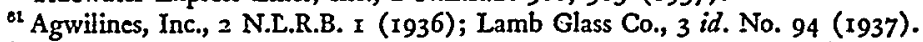

Martin Dyeing and Finishing Co., 2 N.L.R.B. 403 (1936); Stylecraft Leather Goods Co., Inc., 3 id. No. 98 (1937).

a Jones \& Laughlin Steel Corp., I N.LR.B. 503 (1936). 
years a top-notch tractor driver, was discharged for leaving open a door; another, for fifteen years a crane operator, was discharged for leaving a key on a bench; another, whose duty it was to inspect the machinery, was discharged because a nut fell off a crane; another was assigned to new work for which he was not trained and then discharged for spoiling a piece of work. The Board concluded that these employees had been discriminated against with respect to hire and tenure of employment, and the Supreme Court found that the evidence supported the Board's finding that the company discharged these men because of their union activity and for the purpose of discouraging membership in the union. ${ }^{65}$

In the Fruehauf Trailer case, ${ }^{66}$ the discharges were summary, taking place during the day after the men had commenced work, and following in most cases some questioning or warning by the foreman about the employee's participation in union activity. In view of the employer's determination to put a stop to all attempts at unionization, the Board's findings as to discriminatory discharges seem to be clearly justified. In the Friedman-Harry Marks Clothing case, ${ }^{67}$ the Supreme Court upheld the Board's findings that the discharges were because of the membership of the employees in the labor organization and their activities in connection with it. Significant to the Board was the fact that non-union employees replaced those discharged. In the Washington, Virginia and Maryland Coach case, ${ }^{68}$ none of the complainants were told that they were being discharged because of incompetency or inefficiency and the fact that they were discharged over a period of only two days immediately following the organization of the local union, to which the company exhibited strong hostility, and were at once replaced by new employees, satisfied the Board and the Supreme Court that the company looked primarily toward their union membership and activity in terminating their employment. In the Associated Press case, ${ }^{69}$ the employee's activity in the Newspaper Guild was held to be the reason for his discharge. In the Pacific Greyhound case, $^{70}$ it was asserted that a bus driver was discharged because of an accident causing property damages in the amount of fifty dollars. But the bus driver had a splendid record as a driver and had been awarded various tokens of merit, and it was not the policy of the company to discharge operators for such accidents unless they had bad driving records. So the Board concluded that the company had used the accident as a pretext for getting rid of an active and key union organizer.

A discharge or layoff for union activities may violate " 8 (3)" whether or not it is accompanied by a discriminatory refusal to reinstate, ${ }^{71}$ the Board holding that the

${ }^{*}$ NLRB v. Jones \& Laughlin Steel Corp., 30r U. S. I (1937).

* Fruchauf Trailer Co., I N.L.R.B. 68 (1935).

${ }^{\text {er }}$ Friedman-Harry Marks Clothing Co., Inc., I N.E.R.B. 4 II (1936); aff'd, NLRB v. Friedman-Harry Marks Clothing Co., Inc., 30I U. S. 58 (1937).

*s Washington, Virginia and Maryland Coach Co., I N.L.R.B. 769 (x936), aff'd, 30 I U. S. I42 (1937).

The Associated Press, I N.L.R.B. 788 (1936).

${ }^{20}$ Pacific Greyhound Lines, Inc., 2 N.L.R.B. 431 (1936).

"Pennsylvania Greyhound Lines, Inc., I N.L.R.B. I (I935); Pacific Greyhound Lines, Inc., 2 id. 43 I (1936); Remington-Rand, Ine., id. 626 (1937). 
employer is, in such a case, under a duty to offer reinstatement, whether the employee makes application or not. ${ }^{72}$ But where the original termination of employment is not attributable to any wrongful.conduct of the employer, as in the case of a strike or a shut-down due to lack of business, the Board seems to hold that there is no duty to offer reinstatement unless the employee makes application for re-employment. ${ }^{73}$ This application may be made collectively through representatives ${ }^{\mathbf{7 4}}$ and is not a prerequisite where the employer recalls his employees individually or as a group. ${ }^{70}$ The requirement that workers must apply for reinstatement in these cases is objectionable for the reason that they may reasonably expect to return to their jobs upon the termination of the strike or the layoff. Moreover, it is generally agreed that employment relations are not completely' severed by a strike.

A refusal to accept an application for re-employment from an employee who had voluntarily terminated employment has been held to be discriminatory and in violation of " 8 (3)."76 Strikers convicted of minor acts of violence ${ }^{77}$ or of technical trespass $^{78}$ are entitled to reinstatement, and a blacklisting of employees which caused them to delay making requests for employment until their positions were filled, was held equivalent to a discriminatory refusal to reinstate. ${ }^{78}$ Offers of re-employment conditioned upon withdrawal from the union ${ }^{80}$ or joining a company union ${ }^{81}$ or signing a yellow-dog contract ${ }^{82}$ are also equivalent to a refusal to reinstate, and the imposition of such conditions amounts to discrimination in regard to a term or condition of employment in violation of "8 (3)."

Section 2, subdivision 3, of the Wagner Act provides that the term "employee" shall include "any individual whose work has ceased as a consequence of, or in connection with any current labor dispute or because of any unfair labor practice. . .." Independently of statutory definition, 'the courts have generally reached the conclusion that a strike does not of itself result in a complete severance of the employment relation, ${ }^{83}$ but that a new status arises. The term "striking employee" is used as descriptive of this new status, the incidents of which are subject to legislative modification in the public interest. Therefore, the Board seems to be justified in ordering the reinstatement of "striking employees." Such an order of the Board was

72 Washington, Virginia \& Maryland Coach Co., r N.L.R.B. 769 (1936).

${ }^{7}$ Jeffery-De Witt Insulator Co., I N.L.R.B. 618 (1936); Alabama Mills, Inc., 2 id. 20 (1936); Elbe File and Binder Co., id. 906 (1937).

"United Aircraft Mfg. Corp., I N.L.R.B. 236 (1936).

"Atlanta Woolen Mills, I N.L.R.B. 316 (1936); Columbia Radiator Co., id. 847 (1936).

${ }^{76}$ Cherry Cotton Mills, 4 N.L.R.B. No. 89 (1937).

7 Biles-Coleman Lumber Co., 4 N.L.R.B. No. 86 (1937).

${ }^{78}$ Louisville Refining Co, 4 N.I.R.B. No. 1 10 (1938). Accord, as to "sit-down strikers": Indianapolis Glove Co., 5 N.L.R.B. No. 34 (1938); Fansteel Metallurgical Corp., id. No. 124 (1938).

To Mackay Radio and Telegraph Co., I N.L.R.B. 201 (1936).

${ }^{\circ}$ Clark \& Reid Co., Inc., 2 N.L.R.B. 516 (1936).

${ }^{81}$ Clinton Cotton Mills, I N.L.R.B. 97 (1936) (96 former employees who refused to join the Clinton Friendship Association were not re-cmployed).

${ }^{82}$ Alabama Mills, Inc., 2 N.L.R.B. 20 (1936); Carlisle Lumber Co., id. 248 (1936); Lee Clay Products Co., 3 id. No. 83 (1937); Federal Carton Corp., 5 id. No. I1 8 (1938).

(a) Tri-City Central Trades Council v. American Steel Foundries, 238 Fed. 728 (7th, 1917). See discussion by Parker, J. in Jeffery-De Witt Insulator Co. v. NLRB, 91 F. (2d) 134, 137-138 (4th, 1937). 
sustained in the Jeffrey-De Witt case ${ }^{84}$ by the Fourth Circuit Court of Appeals in an opinion by Judge Parker that has been called "an understanding, pioneering job."8s But the Ninth Circuit Court of Appeals in the Mackay Radio and Telegraph case ${ }^{86}$ has taken a contrary position in a two-to-one decision, concluding that the Board had no power to order an employer to reinstate an employee who has terminated his employment by striking. The latter court has apparently changed its opinion about this, because its latest decision upholds a similar order of the Board. ${ }^{87}$ The Supreme Court has granted certiorari in the Mackay Radio and Telegraph case, ${ }^{88}$ so that a decision on whether striking employees are within the protection of the Wagner Act may be imminent. The Mackay case is out of line with general judicial opinion and negatives the express language of the Wagner Act. In addition, if the Mackay case is affirmed, an employer could easily aggravate a strike and then declare the employment relation severed, thus undermining the entire structure of the National Labor Relations Act.

In the cases under " $8(3)$," where there are conflicting contentions as to the cause of the alleged discriminatory treatment, the Board has had to place much weight upon the entire background of the controversy and upon the intention of the employer manifested therein. ${ }^{89}$ What is the motivating force which determines the employee's alleged unfair treatment? The complaint charges a discrimination for the purpose of encouraging or discouraging membership in a labor organization. The complainant therefore has the burden of proving the employer's wrongful motive. It has been suggested that in the cases of discriminatory discharge, when the complainant demonstrates anti-union bias, the burden of going forward with evidence in order to prove the absence of unlawful motive is on the employer. ${ }^{80}$ The background of anti-union hostility is relied upon in so many cases of discriminatory discharge that the suggestion appears to be correct. ${ }^{91}$ The Board, without saying so, seems to require the employer to produce evidence to counteract the effect of proof of anti-union bias, since a discharge plus a background of anti-union sentiment is deemed by the Board sufficient to permit a finding that " 8 (3)" has been violated.92 Other factors which the Board uses as evidence of unlawful motive are (I) previous warnings or threats of dismissal for union activities, ${ }^{93}$ (2) the discharged employee's service record, ${ }^{94}$ (3) the employment of non-union workers to replace the discharged

84 Jeffery-De Witt Insulator Co. v. NLRB, supra note 83. \$ (1938) 6 I. J. A. MoNTHLy BuLL. II5.

* NLRB v. Mackay Radio \& Tel. $\mathrm{Co}_{3}, 92 \mathrm{~F}$. (2d) $76 \mathrm{I}$ (9th, 1937).

or NLRB v. Carlisle Lumber Co., 94 F. (2d) 138 (9th, r937). The decision in the Mackay case was by Justices Wilbur and Matthews, Garrecht, J. dissenting. In the Carlisle case, Justices Haney and Stephens replace Matthews and Garrecht, and Wilbur, J. dissents.

${ }^{\infty}$ NLRB v. Mackay Radio and Tel. Co., 58 Sup. Ct. 644 (1938).

The Board stated this in its first case, Pennsylvania Greyhound Lines, Inc., I N.L.R.B. I, 23 (1935).

${ }^{\infty}$ (1938) 32 ILL. L. REv. 568, 578, n. 96.

"A few recent cases are: Bradford Dyeing Assoc., 4 N.L.R.B. No. 79 (r937); Idaho-Maryland Mines Corp., id. No. 97 (1938); Hopwood Retinning Co., Inc., id. No. II3 (1938); Montgomery Ward \& Co., Inc., id. No. 138 (1938).

lbid.

${ }^{28}$ See cases cited in note 27 , supra.

* The Board has given weight to such factors as length of employment, experience in position from which discharged, efficiency ratings and testimony of foremen and other employees. 
union men, and (4) the discharge of an unduly high percentage of union members or union leaders. It is clear that the employer's improper motive must be a substantial factor in causing the discrimination, although it need not be the sole factor. As we have seen, the Board may find that the employer's reason for dismissing a worker is merely a convenient pretext rather than the motivating cause.

\section{Discharge for Filing Charges}

By Section 8(4), discharging or otherwise discriminating against an employee because he has filed charges or given testimony under this Act is made an unfair labor practice for an employer. Only two cases have arisen under this section, neither presenting any difficulty. In one the discharge was for the filing of charges, the president of the respondent saying, "She may have been laid off before, but she is discharged now, running down there and causing all this trouble." ${ }^{\text {ov }}$ In the other case the discharge was for testifying in a hearing held by the Board on another matter.96

\section{Review of Board's Findings}

Section 10(e) of the Wagner Act provides that "The findings of the Board as to the facts, if supported by evidence, shall be conclusive." ${ }^{97}$ In the Appalachian Electric Power case, ${ }^{88}$ the Fourth Circuit Court of Appeals introduced the word "substantial" into the statute, saying, "We are bound by the Board's findings of fact as to matters within its jurisdiction, where the findings are supported by substantial evidence; but we are not bound by findings which are not so supported. . . . The rule as to substantiality is not different, we think, from that to be applied in reviewing the refusal to direct a verdict at law, where the lack of substantial evidence is the test of the right to a directed verdict. In either case, substantial evidence is evidence furnishing a substantial basis of fact from which the fact in issue can reasonably be inferred; and the test is not satisfied by evidence which merely creates a suspicion or which amounts to no more than a scintilla or which gives equal support to inconsistent inferences. ... If the case had been tried at law, we should unhesitatingly hold that verdict should have been directed against a finding of discrimination or interference on the ground that no sufficient evidence to that effect had been produced." $" 0$

This has been criticized as a judicial amendment of the Wagner Act to permit more extensive judicial review of the work of the Labor Board. ${ }^{100}$ The criticism can only be justified if the Act intended that the Board's findings of fact should be conclusive, if supported by "any" evidence. Parker, J. rejects such an interpretation.

${ }^{\infty}$ Friedman-Harry Marks Clothing Co., Inc., I N.L.R.B. 4II, 428 (1936).

Willard, Inc., 2 N.L.R.B. 1094 (1937).

"7 A similar provision occurs in $\$ 10(f)$.

Appalachian Electric Power Co. v. NLRB, 93 F. (2d) 985 (4th, 1938).

${ }^{90} 93$ F. (2d) 985, 989 (4th, 1938). In Mooresville Cotton Mills v. NLRB, 94 F. (2d) 61, 65 (4th, 1938 ), the same court said, "But the testimony ... was sufficient, if believed, to support the finding and order of the Board. ..."

${ }^{200}$ More Court Decisions on NLRB Orders (March, 1938) 6 I. J. A. MoxithLy BuLL. II5. 
Instead, he uses the words "substantial" or "sufficient" to describe the evidence needed to support the Board's findings and draws a comparison with the review of a.refusal to direct a verdict at law. It might have been clearer to have compared the review of the Board's findings of facts with the review of a jury's verdict. In any case, the test boils down to the same thing, i.e., is the evidence such that reasonable men might have reached the same conclusion? If not, the finding should be set aside. The next step in the development of Administrative Law may be to curtail judicial review of administrative action or remove it altogether, but the rule of substantiality of evidence to support findings, which is applied to the Labor Board, ${ }^{101}$ is the customary technique of permitting courts to say whether an administrative finding of fact is arbitrary or unreasonable. ${ }^{102}$

\footnotetext{
201 "In the case of statutory provisions like Section $10(e)$, applicable to other administrative tribunals, we have refused to review the evidence or weigh the testimony and have declared we will reverse or modify the findings only if clearly improper or not supported by substantial evidence." Roberts, J., in Washington, Virginia \& Maryland Coach Co. v. NLRB, 301 U. S. I42, 147 (1937). A more realistic statement occurs in the recent case of NLRB v. Remington-Rand, Inc., 94 F. (2d) 862, 873 (2nd, r938), where Judge Learned Hand said, ". . . that does not mean that mere rumor will serve to 'support' a finding, but hearsay may do so, at least if more is not conveniently available, and if in the end the finding is supported by the kind of evidence on which responsible persons are accustomed to rely in seribus affairs."

${ }^{30}$ For a suggestive discussion of the desirability of judicial review of administrative action, see Landis, Administrative Law and the Courts (1938) 47 YALE L. J. 519 (1938). In Clark and Stone, Review of Findings of Fact (1937) 4 UNIv. OF Cm. L. REv. 190, 211-213, there is reference to the administrative law problem.
} 